\title{
Empowering Education for Sustainable Futures
}

JESPER MARIUS ALS

\begin{abstract}
This paper positions the role of quality education in the historical and current development paradigm in a global context under the Sustainable Development Goals. I revisit empowering theories and the whole concept of development and connect it to the present. Can such theories guide us in the debate on the future of education? Finally, I reflect on whether my current workplace, a Danish University College, and similar education institutions are at all obliged to tackle global challenges. If so, how can such institutions position themselves to play an essential role in the futures to come? Are there any common denominators in design and content? I draw on my background as a historian and my master's degree in International Relations. From a practical perspective, I draw on what I learned from 15 years of experience working with internationalization and development, both within the UN system, private companies, and later as responsible for large-scale education programs and projects in more than 36 countries. I also draw on six years of experience as chairperson of a Danish NGO working with child protection, alternative care, and deinstitutionalization. Most importantly, I draw on experience as a concerned father of two kids who will be affected by, and dependent on, our current actions.
\end{abstract}

KEYWORDS: Development; Education; Sustainability; SDGs; Empowerment

\section{Development, Education and Social Change}

Well, I think realistically, we have to, first and foremost, educate Samoans to live good lives in Samoa. We also recognize that we are part of a global community, and people go and live elsewhere...I mean, just because they live in Samoa doesn't mean that they don't live in the world. The changes that are happening in how the world organizes itself are very important for Samoan people to understand and to ensure that they can participate benefit from it, but still on the basis that this is where they live. Therefore, education is really the instrument by which people can lead good and useful lives. ${ }^{1}$ (Mataafa, 2002)

This is what the current prime minister of Samoa, Hon. Naomi Fiame Mataafa answered when I interviewed her back in 2002 and asked her, what is the purpose of formal education in

1 Extract from an interview I did with Samoa's Minister of Education Hon. Naomi Fiame Mataafa, Dec $7^{\text {th }}, 2002$, Apia. 
Samoa? Her reply encapsulates the dilemma or challenge that many countries face when designing their education system all the way from Early Childhood Education towards primary, secondary, and tertiary education. Namely, the challenge of balancing local and global. It also paints the potential that education can be empowering and transformative for people to live well. The challenge in this case was and still is that the education system in Samoa needs to fit the realities of both those Samoans who stay in their village and those who are traveling overseas to Pacific Rim Countries and from there contribute to Samoa's economy. Migration and remittances are not only confined to island states but happen in many economies all over the world.

In 2002, I worked at the UNESCO Office to the South Pacific that serves 14 independent Pacific nations. One of my tasks was coordinating a team that synthesized the region's Education for All ${ }^{2}$ plans. The EFA plans supported the Millennium Development Goals that ran from 2000 to 2015 and were replaced by the current Sustainable Development Goals (SDG). The MDGs originate back to when the Development Assistance Committee DAC ${ }^{3}$ in 1996 launched their strategy report 'Shaping the 21st Century'.

Education had a place in the MDGs as it set out to achieve universal primary education. At the beginning of the new millennium, significantly more children were enrolled in formal schooling worldwide. That success stalled around 2007, and by 2015 it was clear that albeit massive investments, that target was not realized fully. The data from the report 'Fixing The Broken Promise of Education For All' shows that the number of primary school age out-ofschool children has dropped by $42 \%$, and for girls by $47 \%$, despite rapid population growth. (UNESCO p.7) A new discussion emerged as it became clear that the quality of education fell simultaneously with the increase of enrolment into formal education, globally. I am not entering a debate on the concept of quality of education. However, I want to accentuate that up to the formulation of the current SDGs, efforts were made to advocate that quality education was fundamental to quality education and sustainable development and, therefore, should be integrated into the new SDG framework. (Paul Ofei-Manu, \& Didham, R. J, 2014).Quality Education is now goal number 4 under the current SDGs. More specifically, goal 4.7 aims to 'by 2030 to ensure all learners acquire knowledge and skills needed to 'promote sustainable development. That includes promoting education for sustainable development and sustainable lifestyles, human rights, gender equality, promotion of a culture of peace and non-violence, global citizenship, appreciation of cultural diversity, and culture's contribution to sustainable development.

\section{Empowerment through Education}

To understand the DNA of the empowering potential that human development harbingered back in 2002, it is worth looking into some of the dynamics behind the economist Amartya Sen's (hereafter Sen) capability approach with attention to enhance freedom and broaden opportunities. His theorem essentially belongs to social justice theory, but at the entrance of the new millennium, Sen was a crucial figure in formulating new ways of understanding development. Sen places a central role on education as an important key to empowering human beings. In his book "development as freedom," his grand synthesis and main argument is that there is more to development than economic progress. Sen's ultimate definition of freedom

2 Education for All was a global movement coined in 1990 in Jomtien.

3 Development Assistance Committee (DAC), international committee acting under the auspices of the Organisation for Economic Co-operation and Development (OECD) 
is the ability for people "to lead the kinds of lives that people have reason to value" (Sen, 1999, p. 3).

Sen sees education as a potential strong institutional setup which might support the above aspiration of empowering people to shape their own future through choices. In a keynote address to the Commission on Population and Development back in 2003, Sen said,

Schooling could be central to human development, in general, and human security, in particular, for several distinct reasons. First, illiteracy and innumeracy were forms of insecurity in themselves. The first and most immediate contribution of successful primary education was to directly reduce one form of deep-rooted insecurity. Second, basic education could be vital in helping people obtain jobs. (Sen, 2003)

A review of his book accentuates that expanding freedom and broadening opportunities implicitly requires the removal of unfreedoms. These are, for example, poverty and tyranny, poor economic opportunities and systematic social deprivation, neglect of public facilities, and intolerance or overactive repressive states. (Cooper, 2000, p. 163)

The arguments against political freedom and civil rights I have experienced in my work seem to come from three different directions. First is the argument that freedoms, rights, and even culture are obstacles to economic progress. Second, the claim that if poor people were given a choice between political freedoms and economic progress they would choose the latter. In other words, that is to say that there is a contradiction between democracy as practice and its justification as a political system. Third, there is a claim that the emphasis on political freedoms, liberties, and democracy is distinctly western and often runs contrary to the cultural values found in non-western societies. Here I shall only outline and elaborate on the third critique as this deals with the issue of cultural values as this is important if we wish to envision futures as plural.

Therefore, Sen tackles the relevant question, "what if some cultures do not regard rights as particularly valuable, compared to other prepossessing virtues or qualities?" (Sen, 1999, p. 223). Here Sen exemplifies with the idea that so-called Asian values contrast rights. Sen dismisses the idea that Asian values should be markedly different from those found in western civilization and challenges the notion of cultural relativism. Sen notes that the emphasis and justification for authoritarian political arrangements have often come from the authorities themselves. (Sen, 1999, p.231) He also reflects on globalization and the alleged movement towards a global monoculture. He acknowledges that in this process, the west has unprecedented power and constitutes a risk to traditional ways of living. Sen claims that, "The threat to native cultures in the globalizing world of today is to a considerable extent, inescapable." (Sen, 1999 p. 240). The remedy is apparently only to smoothen the transition and make sound choices on what to keep and discard. The vanishing of traditions can cause great frustration and a sense of loss. However, Sen says, it is "up to society to determine what, if anything, it wants to do to preserve old ways of living even at a significant economic cost. Ways of life can be preserved if a society decides to do just that, and it is a question of balancing the cost of such preservation with the value that society attaches to the objects and the lifestyles preserved" (Sen, 1999, p. 241). This is basically a cultural cost-benefit analysis but with no predictable answer. Again, Sen draws attention to the freedom and capability and opportunity perspective and closes the discussion by emphasising that freedoms, capabilities, and opportunities should ensure that people are active in the formulation of what to keep and discard. (Sen, 1999)

Another proponent of the empowering potential of education is the Brazilian educational thinker Paulo Freire (hereafter Freire). On an abstract level, Freire asserts that any structure that constitutes a system or institution of oppression should not be regarded as a closed world 
from which there is no exit but as a limiting situation, which the oppressed can transform. (Freire, $p$ 30-33). From this perspective, critical consciousness becomes a necessity in the process of social transformation. Critical reflection and changing the dynamics in the interaction between oppressor and the oppressed constitutes the core of Freire's writing. He identifies the gravest obstacle to this transformation as being that the "oppressive reality absorbs those within it and thereby acts to submerge human being's consciousness." (Freire p. 33). This situation, whereby people get absorbed into an oppressive reality, rests upon seeing the oppressive condition as a natural state of being that creates a passiveness because of the fatalism linked to the condition. "When superficially analyzed, this fatalism is sometimes interpreted as a docility that is a trait of a natural character." In response to this, Freire concludes, "Fatalism in the guise of docility is the fruit of a historical and sociological situation, not an essential characteristic of a people's behavior." (Freire, P. 43). The essence of this thinking has made 'Pedagogy of the oppressed' a powerful message in the way that it reveals the power structures, not only found in the interaction between human beings but also deeply integrated into the institutions upon which society rests.

It is here that Freire puts education under scrutiny. His analysis is very concerned with the psychological aspects of oppression, and this, according to him, is inherent in the formal education system and the teacher-student relationship. He differentiates between the authoritarian 'banking system' and the emancipation of 'dialogue' education. The word 'banking' refers to the idea that students are empty shells that should be filled with information to enhance their intellect. With banking education, the teacher formulates and deposits information, which the student must receive, memorize and repeat. That is, according to Freire, an impediment to what he calls 'conscientizacao', which is the ability to be aware of oneself in the socially constructed world. Or, as Freire Puts it," Conscientizacao refers to learning to perceive social, political and economic contradictions and to take actions against the oppressive elements of reality" (Freire, 1996, p.17). Banking education neglects a constructivist approach to social interaction. It leaves oppressors with a powerful tool to take human beings out of their historical context and statically portrays the world. Freire sums that view up in the following way, "Banking theory and practice, as immobilizing and fixating forces, fails to acknowledge men and women as historical beings" (Freire, 1996 p. 65). That cements Freire's emphasis on humans as historical beings possessing the ability to be aware of the past and the present and actively partake in the formation of the future.

The rejection of the banking education is contrasted by education that pays attention to dialogue. In 'dialogue,' teacher and student together define the world and increase each other's awareness of the surrounding reality. It takes point of departure in a view of education as problem posing, leaving room for students to experiment, use creativity and innovation to solve problems and through 'praxis' or action expose and understand reality. Freire says, "Problem posing education sets itself the task of demythologizing..." [Whereas banking education], "attempts, by mythicizing reality, to conceal certain facts which explains the way human beings exist in the world." (Freire, 1996 p. 64)

\section{The Power of the Development Concept}

Both the MDGs and the SDGs carry the concept of development within them.

The concept or notion of development on the international agenda is young. It is very much linked to the post WW2 Era where development was caught in a rebuilding agenda, later in a bipolar cold war agenda, and not least after 9/11, 2001 with the attack on USA, development is caught up in a complex and fragile security framework. A systematic description of the historical framework and the emergence of the sustainable development idea is drawn in the 
postscript to a recent publication about Sustainable Education (Garsdal 2020). However, I here want to highlight the power of the development idea and the implications that idea might have for the notion of futures in the plural.

In his book, 'Planet Dialectics - explorations in environment and development,' Wolfgang Sachs launches a severe critique of the concept of development. He claims that it essentially undermines nature and social justice. It is, he says, a concept full of emptiness that has failed to grasp the complexity of human existence using dichotomies such as poor/rich and traditional/modern. The uniform, westernized, economy-driven development concept creates a situation where the notion of sustainable development is jeopardized. Sachs advocates that we need to leave the western idea of development and its hidden assumptions and technological glamour and bring other cultures and values to envision different futures (Sachs, 1999, p. 3-27). A similar critique can be found in the book Critical Development Theory. Vincent Tucker in his contribution 'The myth of Development' says that the most extreme statement of universal modernity was when Francis Fukyama proclaimed 'The End of History as it essentially also leads to an end of imagination. Tucker does not share the view of Sachs to abandon the concept of development, arguing that many other ideas, in the same way, have been subject to misuse in power games, globally as well as locally. Instead, he proposes to rehabilitate the concept with a more prominent position for culture and calls for a plurality of development discourses where imagination is still possible. (Munck \& O'Hearn, 2001, p. 19)

From my point of view, bringing in more awareness of culture and the complexity of development processes is essential. It is crucial to make meaningful local solutions and not least design education systems that cater to more than one reality, more than one future. Education as a driver for development is a strong narrative. In my work I have noted how people associate education with possibilities for paid jobs in the formal sector. I have experienced that the empowering narrative of education even creates situations where children, primarily due to poverty, are separated from their families and close relations in the hope that education opens opportunities for a better life in the city. The truth is often very far from that, and in the worst cases, this is linked to severe child abuse issues such as child labor and child trafficking.

The short conclusion is that the concept of development, young as it is, is powerful. If culture is missing in the concept equation, then the visions of development become very linear and uniform and are often guided by economic growth and labor market forces. That in itself makes it hard to talk about futures in the plural.

\section{Our Disempowered Planet in the Hands of Market Forces - a Place for Commons?}

The above critique of the development concept is still relenting. Even today, 23 years later, on a global scale, it still seems that the global economy, rather than fundamental values, morals and ethics, shapes most political decisions and influences our political choices in society. Market forces are global and stronger than ever. Big business is influential in information and consumption, service delivery, etc. All of this add to the complexity of political choices and the possibility for humans to influence their own lives.

Kathrine Richardson, in her contemporary book on the subject of sustainability, draws our attention to the inability of modern western societies to understand our interaction with the planet and nature. Furthermore, she says that education and other social institutions are organized in ways that leave little room to see the broader system. (Richardson p. 8-9) Like Sachs, she sees Sustainable Development as the oxymoron it is and says that the current development paradigm is incompatible with the planet's resources. Basically, this situation illustrates the tension and dilemma inherent in the SDGs - namely the fact that goals 1-6 relating 
to human development might conflict with goals 13-15 concerning environmental protection. The other seven goals can be understood as supporting or underpinning the work with these two groups of goals. (Richardson 2019, P 30-44)

So, how are we able to bridge that conflict and ensure a balanced system where the economy works to support both human wellbeing and a sustainable draw on the planet's resources? It seems, historically, that our present mainstream economic system is not geared to strike that balance. Goal number 10 refers to reduced inequality and suggests better financial markets and institutions regulation. Whereas goal number 8 talks about creating sustainable growth. What does that look like, and can we imagine different economic frameworks other than liberal market-driven capitalism? Kate Raworth has, in her recent book, doughnut economy, given a vision for a different way of thinking about the economy. Her 'doughnut' economy opens up a vision where humans have a safe and just space underpinned by a regenerative and distributive economy between the lower boundaries of social foundation and the upper boundaries of the ecological ceiling. Time and space are not on my side to go into it here, but I only note that the economy may very well be a straightjacket that makes it difficult to bridge the aforementioned conflicting goals. It is hard to imagine a different economic set-up than the one that frames our institutions and guides most of our actions today. It is subsequently even harder to imagine a space for activities that are liberated from the market economy at all.

However, this is what Morten Timmermann Korsgaard touches upon in his article 'Education and the concept of commons. A pedagogical reinterpretation'. The concept of commons or communing is speaking of places or activities that are shared, communal and un-privatized. They are free from capital and market logic. His point is that education is mainly subject to market logic, but it also can escape that, e.g., in the realm between teacher and student. Could SDGs give content to that realm? Could we imagine a future where the broader work with SDGs in educational settings is somehow liberated from market logic?

Noah W. Sobe also touches on a similar view in his short note, 'reworking four pillars of education to sustain the commons. The four pillars are: learning to study, learning to inquire and co-construct together; learning to mobilize collectively; learning to live together in a common world, and not least, Learning to attend and care.

In my years of working globally with education, it is clear that the formal education system always has balanced cognitive and formative aspects and is linked to a national political framework. However, it is also my experience that many education systems are constructed in a manner that is far from the aspirations of Noah and Freire. The new emerging countries most often continued building their education system on the former colonial systems, including the language of instruction, test systems, etc. That still affects equal opportunities and not least systemic exclusion in the education systems. Even worse, from my point of view, the language of instruction policies that deny children to learn and conceptualize the world in their vernacular language fundamentally is problematic concerning the whole notion of becoming and creating their own cultural identity. In 2003 I was sent to Vanuatu and Papua New Guinea and saw this challenge at large. Vanuatu has approximately 270.000 people speaking almost 120 different local languages. That's how culturally diverse the world is.

Despite such differences, it is also interesting to see that education globally shares traits, both in design and content. A central trait is the relationship between teacher and student or master and apprentice. Here, in exactly that trait, Timmerman and Sobe envision communing and commons. I am not suggesting that the SDGs are apolitical. In my view, commons do not mean agreement or uniformity. SDGs are political. In their recent book' bæredygtighedens pædagogik' (translated: The pedagogy of Sustainability) Lysgaard og Jørgensen notes that 
Education for Sustainable development is complex and surrounded by much disagreement. That makes it difficult to approach for educational institutions and requires a dedicated approach and leadership support. However, precisely the same traits make SDGs and ESD perfect for a multidisciplinary educational approach. The SDGs are cross-cutting political, institutional, technical, life-related, relational, moral, existential, and emotional boundaries. (Lysgaard \& Jørgensen, 2021)

\section{Knowledge, Praxis, and Attitude for the Coming Futures}

How can we then possibly relate or link some of the ideas behind Sen and Freire's view on empowering education to the current global situation and the issue of education for sustainable futures?

We live in a time of great interconnectedness. Yet, to a large degree, human beings are removed from nature and the resources we use to support our ways of living. The direct consequences of our local actions are hard to understand, even with a critical outlook, and make it challenging to act responsibly. That may very well leave human beings with a feeling of disempowerment and apathy.

My years of working with development issues around the globe have taught me that development processes are extremely complex. Especially if we, as Tucker proposes, pay more attention to the cultural aspects and the diversity that follows. It is, for example, an industrious task to understand the interconnectedness on a local scale in a Samoan village setting and recognize, for example, the democratic traits of local institutions, representation, and organization to secure wellbeing. That is, however, important if we want to engage constructively in a dialogue around education to support, for example, community processes and their connection to global forces and link the local and the global.

Amartya Sen reminds us precisely of this complexity, as his capability approach is dependent on the dynamic of many different factors. What is questionable is if Sen's notion of people's freedom to choose what value is still an option with the planet's current state. We in western societies are now proposing limits to the so-called developing world and asking them to live differently than we have done in terms of resources. It is indisputable that humankind faces unprecedented challenges globally, and the planetary boundaries and our development paradigm potentially undermine our own existence as a species. That is the dilemma underpinning our Anthropocene era.

Of course, the great question is whether education systems are at all morally obliged to, and capable of, preparing students to act on those challenges. I would argue so. In his book 'Mod til at vælge,' the Spanish Philosopher Fernando Savater reminds us that the ultimate principle for human beings, or rather, for being human is the ability to reflect and act. He also explores the concept of freedom, and with references to earlier philosophers, he frames the human being by its freedom or rather ability to act. To act is not a choice but a fundamental necessity for our survival, and interestingly Savater notes that "to act is to design virtual situations that do not exist yet, by means of a symbolic range of opportunities, opening unknown and very differentiated futures." (Savater, p. 16-25, translated into English from Danish translation of Spanish original)

Freire reminds us that emancipation and empowerment rest on being able to dialogue and the ability to open our understanding of realities in a dialectical process. That is exactly what Education for Sustainable Development and the SDGs has the potential to do. It is my claim that if the education systems of today and in the future do not manage to make students informed, knowledgeable, able to act in practice and not least feel responsible for acting 
(attitude and values), then we are, in a Freirian perspective, disempowering the coming generations. Their feeling of responsibility is very dependent on knowledge and action competencies and, of course, the opportunity to choose to act.

Therefore, I believe over the next 30 years, global education systems need to address the issue of their own sustainability, understood as the following two pillars:

1. Their ability to enable people to navigate both locally and globally, as pointed out by the Samoan minister in the opening statement. That necessitates, from my point of view, that the formal education policies take into consideration local context by placing a significant degree of autonomy locally and revise the way education is financed and organized all the way from policy to curricula content.

2. Their ability to draw significantly more attention on the formative aspects of education at all levels of the system. The planet's current state requires a revision of the fundamental relation between humans and nature. It might be possible to imagine a future formative framework that precisely rests on such a reinvention and connects the formative aspects to the skills needed to act accordingly. In other words, alignment between the purpose of education and the envisioned relevant skills.

\section{The Important Role for Practice-Oriented Higher Education}

University Colleges have a unique position to work with the SDG framework and use it as a relevant framework for working with sustainability, strengthening intercultural competencies, and not least building a global mindset for global citizenship. That can be done through the university college's very own DNA, which is to educate students for professions in society. But not in isolation! The unique position for university colleges, polytechnics, and alike is their connectivity to business, industries, other state institutions, and the broader population through welfare professions like health care workers, teachers, social workers, and social educators. The magnitude of the university college's possibility to influence is immense and needed to make a pedagogical paradigm shift and re-establish a connection between human beings and nature. From this perspective, it is from such a perspective that talks about welfare solutions, products, and services of private companies and civil society organizations and activities should take place. If Kathrine Richardson is right that we lack systemic thinking, then the interconnectedness between society's actors - state, market and civil society - should be strengthened even more and work towards common challenges.

That is already happening. I am currently following courses on sustainability leadership and studying with people from all the above-mentioned spheres. It is interesting to see that the pressure to work with the SDGs comes from many sides, e.g. (consumer) demand-driven, policy (rules, guidelines, and regulation), profit-driven (companies), and not least from the voiceless planet itself. This shift is happening with great speed, and if university colleges want to prepare students for a future labour market then sustainability should be on top of mind. University colleges are, however, from my perspective, not just mandated to deliver a workforce for the future. We have an obligation to bridge new knowledge to praxis and even challenge our politicians on the very design of society (state, market, and civil society). The challenges globally are complex and require cross-disciplinary approaches when addressed.

VIA University has started its journey towards addressing the issue of sustainability and has taken the task seriously. In the newly formulated strategy, sustainability has a rightful place. Groups in VIA are actively working to address both VIA's own sustainability, understood as our 
foot and handprints. But also holistically, how Education for Sustainable Development (ESD) is integrated into the professions. The SDGs are normative in their appearance. There is no prescription attached to how to accomplish the goals, and it is up to individuals, institutions, companies, governments, etc., to figure out how to work with them. That is another reason why they are a challenge. Hence, the ability of the teacher is paramount in that equation to ensure that the future challenges are, in a Freirean sense, demystified and dialectically understood and addressed.

From my point of view, the international dimension of education has a vast potential to lift the work with ESD. The overall goal of internationalization, apart from inspiring and mirroring our professions, is to enhance the intercultural competencies of students. Intercultural competencies share some of the same unifiers that Sobe points towards e.g., empathy, respect for diversity, and the ability to collaborate constructively across borders and cultural differences. VIA's international unit, Global Engagement, where I am currently placed as an international adviser, collaborates with all professions working actively to promote that. When embarking further on our journey, I believe it is essential to look into how to activate both local and global dimensions of ESD. From my perspective, here we can open up the systemic thinking that Richardson calls for and the emancipative call that Freire advocates. It is in the span between global commons and local actions that will be paramount in the futures that are ahead. It was so back in 2002, it still is, and it will be.

\section{Epilogue}

Some weeks ago, The International Commission on the Futures of Education launched their publication 'Reimagining Our Futures Together - A new Social Contract for education.' It is interesting to note how the word imagining is used to frame the process. Fernando Savater reminded us that acting starts with designing virtual situations that do not exist yet, through a symbolic range of opportunities, opening unknown and very differentiated futures. That report is precisely an invitation for these kinds of imaginations that can hopefully lead to action. It will be interesting to see the position the report imagines for bridging local and global and envisions commons to support the more formative dimensions of education.

\section{Literature}

Amartya Sen (1999) Development as Freedom: Oxford University Press

Cooper, R. N. (2000). The Road from Serfdom: Amartya Sen Argues That Growth Is Not Enough [Review of Development as Freedom, by A. Sen]. Foreign Affairs, 79(1), 163-167. https://doi.org/10.2307/20049621

Garsdal, J. (2020). Efterskrift: om begrebet bæredygtig udvikling. I J. Garsdal (red.), Bæredygtighed og bæredygtig udvikling: uddannelse, dannelse og fagdidaktik i skole, erhvervs- og professionsuddannelser (s. 92-123). VIA University College.

Jonas Andreasen Lysgaard \& Nanna Jordt Jørgensen (2020) Bæredygtighedens pædagogik forskningsperspektiver og eksempler fra praksis.

Kathrine Richardson (2019) hvordan skaber vi bæredygtig udvikling for alle?; Kathrine Richardson og Informations forlag

Kate Raworth (2018) Doughnut $\varnothing$ konomi - 7 principper for fremtiden $\varnothing$ konomi: Kate Raworth og Informations forlag

Morten Timmermann Korsgaard (2019) Education and the concept of 
commons. A pedagogical reinterpretation, Educational Philosophy and Theory, 51:4, 445-455, DOI:10.1080/00131857.2018.1485564

Paul Ofei-Manu, \& Didham, R. J. (2014). Quality Education for Sustainable Development: A priority in achieving sustainability and well-being for all. Institute for Global Environmental Strategies. http://www.jstor.org/stable/resrep00748

Paulo Freire (1996) Pedagogy of the Oppressed: penguin Books, London

Ronaldo Munck \& Dennis O'Hearn (2001) Critical Development Theory, Contributions to a New Paradigm: Zed Books, London and New York

REIMAGINING OUR FUTURES TOGETHER, A new Social Contract for education (2021), Report from the Inernational Commission on the Futures of Education.

Savater, F. (2005). Mod til at vælge. Kbh: People's Press. [translated from Spanish: Savater, F. (2003). El Valor de elegir. Barcelona: Ariel]

Sobe, N. W. (10 February 2021) Reworking Four Pillars of Education to Sustain the Commons. UNESCO Futures of Education Ideas LAB. Retrieved from https://en.unesco.org/futuresofeducation/ideas-lab/sobe-reworking-four-pillars-educalan-sustain-commons

UNESCO Institute for Statistics (UIS) and UNICEF (2015). Fixing the Broken Promise of Education for All: Findings from the Global Initiative on Out-of-School Children. Montreal: UIS. http://dx.doi.org/10.15220/978-92-9189-161-0-en

Wolfgang Sachs (1999) Planet Dialectics, Explorations in Environment and Development: Zed Books, London and New York 